GRASAS Y ACEITES 71 (4)

October-December 2020, e383

ISSN-L: 0017-3495

https://doi.org/10.3989/gya.0794191

\title{
Cocoa olein glycerolysis with lipase Candida antarctica in a solvent free system
}

\author{
L.S. Zamorano ${ }^{\mathrm{a}, \varpi}$, P. Calero Magaña ${ }^{\mathrm{a}}$, E. García Cisneros ${ }^{\mathrm{a}}$, A.V. Martínez ${ }^{\mathrm{b}}$ and L.F. Martín ${ }^{\mathrm{b}}$ \\ ${ }^{a}$ Oleofat Trader S.L, Ciudad Agroalimentaria, Pol. Industrial La Serna, Calle C, nave 6.19, 31500 Tudela, Navarra. T +34 948415887. \\ bAsociación de la Industria Navarra, Ctra. Pamplona 1, Edificio AIN. 31191 Cordovilla, Navarra. T +34 948421 101, F +34 948421100. \\ ${ }^{\square}$ Corresponding author: 1sanchez@oleofat.es
}

Submitted: 22 July 2019; Accepted: 26 November 2019; Published online: 3 November 2020

SUMMARY: In this paper we present the valorization of cocoa olein obtained from the acid fat-splitting of soapstocks. The aim is to develop a solvent free process (enzymatically catalyzed) to maximize the production of a final product with high content of monoglycerides (MAG) and diglycerides (DAG). The effect of the enzyme dose, glycerol content, reaction times as well as the modification of the raw material and pressure were studied. The yield of the reaction increased up to $90-95 \%$ when using a vacuum of $2-3 \mathrm{mbar}$ at $65^{\circ} \mathrm{C}$, enough to evaporate the water which is generated as a by-product, an enzyme dose of $1 \%$ and molar ratio oil:glycerol of 1:2. The highest yield in terms of MAG and DAG production was obtained by starting from a raw material which was rich in free acidity (FFA), rendering oil with 33.4 and $44.2 \%$ MAG and DAG, respectively. Short reaction times (6-8 h) were observed compared to previously reported results $(24 \mathrm{~h})$.

KEYWORDS: By-products; Diglyceride; Enzymatic Glycerolysis; Lipase CALB; Monoglyceride; Olein

RESUMEN: Glicerólisis de oleínas de cacao con lipasa Candida antarctica en un sistema libre de solventes. En el presente trabajo se pretende valorizar la oleína vegetal de cacao procedente de la ruptura ácida de las pastas de refinación química. El objetivo es poner a punto un proceso de glicerólisis enzimática en un sistema libre de solventes maximizando la producción de monoglicéridos (MAG) y diglicéridos (DAG). Se ha estudiado el efecto de la dosis de enzima, el contenido de glicerol y el tiempo de reacción, la modificación de la presión de reacción y la composición de la materia prima. Se concluye que el rendimiento de la reacción aumenta hasta el 90-95\% cuando se aplica un vacío de $2-3$ mbar a $65{ }^{\circ} \mathrm{C}$ suficiente para evaporar el agua que se va generando como producto, una dosis de enzima del 1\% y una relación molar aceite:glicerol 1:2. El mayor rendimiento en cuanto a la producción de MAG y DAG se ha conseguido partiendo de una materia prima rica en acidez libre (FFA), obteniéndose un aceite con un 33.4 y 44.2\% de MAG y DAG, respectivamente. Se observa que los tiempos de reacción son cortos (6-8h) comparados con los descritos en la bibliografía encontrada (24h).

PALABRAS CLAVE: Diglicéridos; Glicerólisis enzimática; Lipasa CALB; Monoglicéridos; Oleína; Subproductos oleaginosos

ORCID ID: Zamorano LS https://orcid.org/0000-0002-7467-4062, Calero Magaña P https://orcid.org/00000003-4866-6031, García Cisneros E https://orcid.org/0000-0002-8677-2591, Martínez AV https://orcid.org/00000001-7276-5588, Martín LF https://orcid.org/0000-0001-7021-0247

Citation/Cómo citar este artículo: Zamorano LS, Calero Magaña P, García Cisneros E, Martínez AV, Martín LF. 2020. Cocoa olein glycerolysis with lipase Candida antarctica in a solvent free system. Grasas Aceites 71 (4), e383. https://doi.org/10.3989/gya.0794191

Copyright: (C2020 CSIC. This is an open-access article distributed under the terms of the Creative Commons Attribution 4.0 International (CC BY 4.0) License. 


\section{INTRODUCTION}

Oleins are obtained as a by-product in the process of the fat splitting of soapstocks, but they have low market value because they are a mixture of free fatty acids and TAG. At least $50 \%$ of it is constituted by free fatty acids and $40 \%$ by TAG, with the remaining $10 \%$ being MAG, DAG, unsaponifiable lipids and, to a lesser extent, methyl and ethyl esters.

Oleins obtained from the fat-splitting of soapstocks have various uses, including the manufacture of animal feed (fat additive) as well as other multiple technical uses by employing olein as such or via some of their derivatives obtained by chemical transformation. The most widespread use is the manufacture of biodiesel (Ribeiro et al., 2011; Narvaez Rincón et al., 2004; Pereda Marín et al., 2003), for which the olein is subjected to a process of chemical esterification with methanol catalyzed by acids (Otadi et al., 2011) and subsequently to a process of chemical transesterification catalyzed by a strong base. As a result, free fatty acids (FFA), as well as MAG, DAG and TAG can be transformed into methyl esters (FAMEs).

MAG and DAG are biodegradable compounds classified as GRAS (Generally Recognized As Safe) by the FDA (Food Drug Administration). These molecules are used as anionic surfactants, emulsifiers and stabilizers (E471) (Camino Feltes et al., 2013) for the food industry (bakery products, dairy products, and other products that may contain milk or flour) as well as for the textile industry and the plastic and biolubricant industry (formulations of oils for use in different types of machinery). They have proven to be so versatile that MAG has even shown to have antimicrobial activity (Ramesh et al., 2017). Their production, using both chemical and enzymatic reactions, can reach $90 \%$ yields when carried out in organic solvents (hexane, toluene, chloroform, acetone, etc). The disadvantage of using this type of solvents is that, in addition to denaturing the enzymes, they are toxic, carcinogenic, flammable and not biodegradable. In addition, a further purification step for the final product is required to remove these chemicals.

The glycerolysis reaction from oleins produces oils which are rich in MAG and DAG. This process can be carried out chemically or enzymatically, with the industry favoring the chemical approach (Satriana et al., 2016). Such a process is carried out with a basic catalyst $\left(\mathrm{NaOH}, \mathrm{KOH}\right.$ or $\left.\mathrm{Ca}(\mathrm{OH})_{2}\right)$, at high temperatures $\left(190-250{ }^{\circ} \mathrm{C}\right)$, for 3-5 h with constant agitation. The final product resulting from the reaction under these conditions usually has the following composition: MAG 30-60\%, DAG 35-50\% and TAG $1-20 \%$, with certain residual acidity. Thus, in order to achieve a concentration of over $80 \% \mathrm{MAG}$ and DAG in the final product, a further process of molecular distillation is needed (Ramesh et al.,
2017; Solaesa et al., 2016). Consequently, the current industrially implemented processes of chemical glycerolysis tend to entail costly energy demands and have additional drawbacks, such as raw material degradation and darkening of the desired product due to the use of very aggressive catalysts. When a minor degradation of raw material is required, the use of $\mathrm{Ca}(\mathrm{OH})_{2}$ as a catalyst is preferred. However, although smaller, the use of this catalyst cannot prevent the degradation of a significant part of the unsaturated fatty acids (Solaesa et al., 2016; Tiankui et al., 2005), with the subsequent reduction in the potential health benefits of the oil.

Enzymatic glycerolysis has several advantages over chemical glycerolysis (Fregolente et al., 2008; Csanadi et al., 2009; Kapoor et al., 2012; Camino Feltes et al., 2012). The main ones are lower working temperatures $\left(50-80^{\circ} \mathrm{C}\right)$ and a reaction $\mathrm{pH}$ close to neutrality ( $\mathrm{pH}$ 5.0-6.0), both having a direct impact on the quality improvement of the obtained final products. Also, energetically speaking, the process is a less costly one that can be easily scaled up and implemented at industrial scale, generating fast economic benefits and returns. However, it also has disadvantages, with the main one being the high costs associated with the enzymatic catalyst. To give some estimation of costs, increasing the enzyme load from 0.5 to $1 \%$ doubles the process costs.

Nonetheless, enzymatic catalyst is a highly viable process leading to a final product with MAG concentrations similar to or even higher than those obtained by the chemical route with the added benefit of a less degraded product (Solaesa et al., 2016; Tiankui et al., 2005).

Lipases (E.C. 3.1.1.3) belong to the family of hydrolases, since they catalyze the hydrolysis of TAG at the lipid-water interface. In addition to their physiological roles, lipases catalyze the hydrolysis or enantio- and regio-selective synthesis of a wide variety of natural substrates, as well as carrying out esterification, interesterification and transesterification reactions in non-aqueous media. This versatility explains why this enzymatic group has a great biotechnological application in the oil industry (Fariha et al., 2005; Godfrey T, 2005; Rivera-Pérez et al., $2007)$, and in the production of drugs, agrochemicals, etc. The main lipases of industrial interest are produced by fungi (Candida cylidracae, Aspergillus niger, Candida rugosa, Candida antarctica, Mucor miehei, Staphylococcus aureus, Rhizopus arrhizus, etc.); whereas others are extracted from bacteria. Some are non-specific enzymes, while others act specifically on a very precise fragment of the TAG. There is also another group of lipases that can work at slightly higher temperatures $\left(60-75^{\circ} \mathrm{C}\right)$ namely, thermostable lipases. CALB is a non-specific enzyme capable of attacking the three positions (sn-1, 2 and 3 ) of the TAG molecule to produce glycerol and free fatty acids (Grazia et al., 2015). Regardless of the 
different features of this great family of enzymes, the great advantage of the use of lipases (for low temperature fat processing processes) lies in their ability to significantly reduce the formation of trans fats, which are formed in high amounts in homologous chemical processes (Rivera-Pérez et al., 2007).

For all the reasons mentioned above, the objective of this research is to develop an enzymatic technology in a solvent-free system (Noureddini et al., 1998; Valerio et al., 2010; Vazquez et al., 2016; Wiphum et al., 2005; Zhao et al., 2013; Ziobrowski et al., 2009), with yields close to $80 \%$ (joint content of MAG and DAG).

The reaction of any Gycerolysis can be seen in Eqs. 1-3.

\begin{tabular}{llll}
$\mathrm{TAG}+$ Glycerol & $\longrightarrow$ & $\mathrm{DAG}+\mathrm{MAG}$ & Eq.1 \\
$\mathrm{DAG}+$ Glycerol & $\longrightarrow$ & 2MAG & Eq.2 \\
\hline TAG + 2Glycerol $\longrightarrow$ & 3MAG & Eq.3
\end{tabular}

Finally, it is also worth mentioning that since oleins contain a high concentration of FFA (free acids concentration can represent up to $50-70 \%$ of the olein), the typical reactions of glycerolysis (Eqs. 1 to 3) compete with the reaction between glycerol and FFA (direct esterification), resulting in the glycerolysis of oleins in a set of competing reactions (Eqs. 4 to 7). A secondary reaction of direct esterification (Eq. 5) reduces the concentration of MAG but unfortunately cannot be avoided, as they happen simultaneously. Both types of syntheses lead to a balance which shows a greater shift to the right as the temperature and reaction time increase (Chemical Glycerolysis).

$$
\begin{array}{llll}
\mathrm{FFA}+\text { Glycerol } & \longrightarrow & \mathrm{MAG}+\mathrm{H}_{2} \mathrm{O} & \text { Eq.4 } \\
\mathrm{MAG}+\mathrm{FFA} & \longrightarrow & \mathrm{DAG}+\mathrm{H}_{2} \mathrm{O} & \text { Eq.5 } \\
\mathrm{DAG}+\mathrm{FFA} & \longrightarrow & \text { TAG }+\mathrm{H}_{2} \mathrm{O} & \text { Eq.6 } \\
\cline { 1 - 2 } & \longrightarrow & \text { TAG }+\mathbf{3} \mathbf{H}_{2} \mathbf{O} & \text { Eq.7 }
\end{array}
$$

Thus, when the raw material has a high acidity value, such as oleins, the composition in the final product of the glycerolysis reaction is higher in
TAG (up to $15-25 \%$ of total) compared to products obtained from other sources.

In this research we have studied the enzymatic glycerolysis reaction of cocoa olein in a solvent-free medium. We will study the effect of the enzyme concentration (dose), glycerol concentration, reaction time and vacuum effect in the final composition of the product (FFA and MAG, DAG and TAG contents).

\section{MATERIALS AND METHODS}

\subsection{Materials}

The raw material used in the experiments was an olein from cocoa (Theobroma cocoa) soapstocks, obtained from OLEOFAT TRADER S.L. (Tudela - Navarra -Spain) by acid fat-splitting. Cocoa soapstocks were provided by Moner Cocoa S.A. (La Selva del Camp - Tarragona - Spain). The enzymes Lipozyme CALB and Eversa transform 2.0 were purchased from Novozymes (Bagsværd -Copenhagen). Glycerol (99.9\%) was purchased from Labbox, $\mathrm{NaOH}, \mathrm{KOH}$ and the solvents used for analysis (ethanol, $n$-hexane, diethyl ether, methanol and acetone) were from Scharlab. The HMDS+TMCS+Pyridine 3:1:9 (Sylon HTP) mix used to quantify MAG, DAG and TAG and the internal standards such as 1,2,4-butanetriol and tricaprin were purchased from Supelco (Sigma Chemical Co., St Louis, MO). The standards for the calibration curves in the GC analysis, 1-Monolarin, Diolein, Triolein and glycerol, were purchased from Larodan and the $30 \mathrm{mg} / \mathrm{ml}$ FAME mix (28 components) was purchased from Restek.

\subsection{Methods}

\subsubsection{Enzymatic glycerolysis}

The enzymatic glycerolysis reaction was performed in a batch system (Figure 1; Table 1). Raw material (200 gr cocoa olein) was placed in the reactor and $0.8 \% \mathrm{NaOH}$ (oil weight) was added in order to reach a $\mathrm{pH}$ of 5.5 (the olein had a $\mathrm{pH}$ of 3.88) (Table 2). After this glycerol was added up to a concentration of $7.0-46.0 \%(\mathrm{w} / \mathrm{w})$, with molar ratios

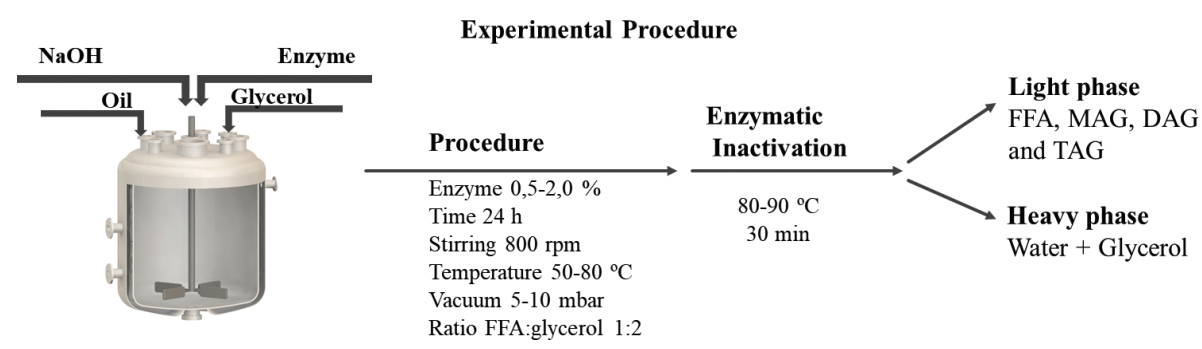

FIGURE 1. Enzymatic Glycerolysis procedure: reaction conditions, raw material, reagents and final products of the reaction. 
TABLE 1. Experimental conditions of Enzymatic reactions.

\begin{tabular}{llcccccccc}
\hline Enzymatic reaction & Enzyme & $\begin{array}{c}\text { Temperature } \\
\left({ }^{\circ} \mathbf{C}\right)\end{array}$ & $\begin{array}{c}\text { Time } \\
\mathbf{( h )}\end{array}$ & $\mathbf{p H}$ & $\begin{array}{c}\text { Stirring } \\
(\mathbf{r p m})\end{array}$ & $\begin{array}{c}\text { Dose } \\
(\mathbf{\%})\end{array}$ & $\begin{array}{c}\text { Vacuum } \\
(\mathbf{m b a r})\end{array}$ & $\begin{array}{c}\text { Glycerin } \\
(\mathbf{\%} \text { w/w) }\end{array}$ & $\begin{array}{c}\text { Water } \\
\mathbf{( \% )}\end{array}$ \\
\hline Glycerolysis & Lipozyme CALB & 65 & 24 & $5.5-6.0$ & 800 & $0.2-2.0$ & $1-2$ & $7-35$ & $1-3$ \\
Hydrolysis & Eversa transform 2.0 & 55 & 24 & $5.5-6.0$ & 400 & $0.5-2.0$ & No & 0 & 50 \\
\hline
\end{tabular}

TABLE 2. Composition of cocoa olein, raw material used in this study. ${ }^{(1)}$ MAG (monoglycerides); DAG (diglycerides) and TAG (triglycerides).

\begin{tabular}{|c|c|c|c|c|c|c|c|}
\hline Acidity (\%) & Unsaponifiable (\%) & pH & Water (\%) & MAG $^{(1)}(\%)$ & $\operatorname{DAG}^{(1)}(\%)$ & TAG $^{(1)}(\%)$ & Melting point $\left({ }^{\circ} \mathrm{C}\right)$ \\
\hline 46.3 & 1.66 & 3.88 & 1.13 & 2.70 & 7.70 & 38.90 & 36.0 \\
\hline \multirow{2}{*}{\multicolumn{2}{|c|}{ Fatty acid profile (\%) }} & C16:0 & C18:0 & C18:1 (cis-9) & C18:2 (cis-9, 12) & C18:3 (cis-9, 12, 15) & C22:0 \\
\hline & & 30.94 & 26.21 & 40.32 & 0.82 & 0.80 & 0.89 \\
\hline
\end{tabular}

oil:glycerol between 1:0.5 and 1:2, depending on the composition of the desired final product.

Thus, when high doses of MAG are desired a higher dose of glycerol is needed (molar ratio oil:glycerol up to 1:1); whereas in a reaction intended for the production of TAG the molar ratio of oil:glycerol must be increased (working with a stoichiometric defect of glycerol). Finally, the enzyme Lipozyme CALB was added (0.5-3.5\% of oil weight). CALB is a non-specific enzyme capable of attacking the three positions (sn-1, 2 and 3) of the TAG molecule to produce glycerol and free fatty acids.

The glycerolysis reaction was carried out at $65{ }^{\circ} \mathrm{C}$, for $24 \mathrm{~h}$, at $800 \mathrm{rpm}$ and with controlled vacuum (2-3 mbar) using a vacuum pump. The enzyme was thermally denatured at $85{ }^{\circ} \mathrm{C}$ for 30 min, the final product was decanted after $1-2 \mathrm{~h}$ to separate the heavy phase, which contained the water and glycerol produced during the glycerolysis reaction. The acidity as well as the MAG, DAG and TAG profile were analyzed in the upper phase with acid base titration and a GC-FID-on-column system, respectively. In this work, all the reactions were performed in duplicate.

\subsubsection{Enzymatic hydrolysis}

The enzymatic hydrolysis reaction was performed based on previous works in a batch system (Goswami et al., 2012). The conditions are shown in Table 1. Raw material (cocoa olein) was placed in the reactor $(2000 \mathrm{~g})$ then $0.8 \% \mathrm{NaOH}$ (oil weight) was added to reach a $\mathrm{pH}$ of 5.5 , since e olein has a $\mathrm{pH}$ of 3.88 (Table 2). Then water was added $(50 \%$ $\mathrm{v} / \mathrm{v})$ followed by the enzyme Eversa transform 2.0 ( $1 \%$ of oil weight). Temperature and stirring were set at $55^{\circ} \mathrm{C}$ and $400 \mathrm{rpm}$ for $24 \mathrm{~h}$ for the hydrolysis reaction. The enzyme was thermally denatured at $85{ }^{\circ} \mathrm{C}$ for $30 \mathrm{~min}$, and the final product was decanted after 1-2 $\mathrm{h}$ to separate the heavy phase, which contained water and the glycerol produced during the hydrolysis reaction. Acidity was analyzed in the upper phase with acid base titration.

\subsubsection{Chromatographic analyses: $M A G, D A G$ and $T A G$ profile}

The chromatographic analyses were carried out using an Agilent 6890N gas chromatograph, equipped with on-column injector and a flame ionization detector (FID). A DB-5HT capillary column (15 m x $0.32 \mathrm{~mm}$ i.d.) was used for the GC separation. $1 \mu$ of sample was injected using hydrogen as carrier gas with linear velocity of $1 \mathrm{ml} / \mathrm{min}$ and flame ionization detector at $380^{\circ} \mathrm{C}$. The column oven temperature program was $50{ }^{\circ} \mathrm{C}$ ( $1 \mathrm{~min}$ ), $15^{\circ} \mathrm{C} / \mathrm{min}$ up to $180{ }^{\circ} \mathrm{C}, 7^{\circ} \mathrm{C} / \mathrm{min}$ up to $230{ }^{\circ} \mathrm{C}, 30^{\circ} \mathrm{C} / \mathrm{min}$ up to $380^{\circ} \mathrm{C}$ (held for $15 \mathrm{~min}$ ); on-column injector with direct injection mode and temperature at $70{ }^{\circ} \mathrm{C}$ (held for $1 \mathrm{~min}$ ), $20{ }^{\circ} \mathrm{C} / \mathrm{min}$ up to $380{ }^{\circ} \mathrm{C}$ (held for $10.31 \mathrm{~min}$ ). The standard mixtures and samples $(100 \mu \mathrm{l}$ to $10 \mathrm{mg} / \mathrm{ml})$ were silylated with $100 \mu \mathrm{l}$ MSTFA, and after $20 \mathrm{~min}$, $8 \mathrm{ml} n$-heptane were added. The retention time of the first internal standard (1,2,3-butanetriol) was used to identify glycerin and the retention time of the second internal standard (tricaprin) was used to identify the mono-glycerides, diglycerides and triglycerides. Glycerin, monoolein, diolein and triolein were used to calculate the linear calibration curves.

\subsubsection{Acid base titration}

The acidity of the oil was determined using an acid-base titration according to ISO 660:2009 standard and using an automatic titrator (HI901 from Hanna Instruments). Oil (0.3-1.0 g) was dissolved in $100 \mathrm{ml}$ of diethyl ether:ethanol 50:50 (v/v) and the sample was titrated with an ethanolic solution of $\mathrm{KOH} 0.1 \mathrm{~N}$. 


\subsubsection{Melting point}

The melting point of the oils was determined following the open capillary tube method, which was immersed in water under stirring and heating according to AOCS method Cc 3-25 (2004).

\subsubsection{Determination of fatty acid composition}

Fatty acid composition was analyzed by gas chromatography (GC) after methylation of the fatty acids to fatty acid methyl esters (FAMEs) using a chromatograph Varian 430 model equipped with a flame ionization detector (FID) and a Supelco SP2380 $60 \mathrm{~m} \times 0.25 \mathrm{~mm} \times 0.2 \mu \mathrm{m}$ capillary column. About $50 \mu \mathrm{l}$ of oil were methylated by adding $150 \mu \mathrm{l}$ of $\mathrm{KOH} 2 \mathrm{~N}$-methanol in a glass tube. The mixture was stirred for 30 seconds and $1 \mathrm{ml}$ of hexane was added. The process conditions were: $\mathrm{N}_{2}$ as a carrier gas with $0.9 \mathrm{ml} / \mathrm{min}$ flow, FID at $250^{\circ} \mathrm{C}$, injector (1:100 split ratio) at $250^{\circ} \mathrm{C}$ and injection volume of $1 \mu$ l. The column temperature was programmed to $2 \mathrm{~min}$ at $60{ }^{\circ} \mathrm{C}$ followed by an increase to $240{ }^{\circ} \mathrm{C}$ at $8{ }^{\circ} \mathrm{C} / \mathrm{min}$. The peaks of individual fatty acids were identified by comparing the retention times of known mixtures of fatty acid standards (FAME mix (28 components) injected in similar conditions. The results were expressed as percentages in relation to the total fatty acids.

\subsubsection{Determination of unsaponifiable matter}

To determine the degree of unsaponifiable matter, a method of extraction with diethyl ether was used (ISO 3596:2002). Oil (5 g) was saponified with $50 \mathrm{ml}$ of $\mathrm{KOH} 1 \mathrm{M}\left(65^{\circ} \mathrm{C}, 300-400 \mathrm{rpm}, 1 \mathrm{~h}\right)$ and subsequently washed with $100 \mathrm{ml}$ of distilled water and $100 \mathrm{ml}$ of diethyl ether. The organic phase was washed with distilled water $(3 \times 40 \mathrm{ml})$, $\mathrm{KOH} 0.5 \mathrm{M}(3 \times 40 \mathrm{ml})$ and once again distilled water $(3 \times 40 \mathrm{ml})$, after which the diethyl ether was evaporated on a rotary evaporator at $50{ }^{\circ} \mathrm{C}$. The quantity of unsaponifiable matter was calculated by weight.

\section{RESULTS AND DISCUSSION}

\subsection{Raw material: cocoa olein}

Cocoa olein results from the acid fat-splitting with $\mathrm{H}_{2} \mathrm{SO}_{4}$ of cocoa soapstocks. Likewise, cocoa soapstocks are obtained when cocoa oil is refined using a chemical neutralization with $\mathrm{NaOH}$ in order to reduce the acidity in the cocoa oil. Cocoa soapstocks are light brown, they smell like chocolate and they are solid at room temperature, with a $\mathrm{pH}$ over 12.0. The composition and free fatty acid profile of the cocoa olein were determined (Table 2).

\subsection{Effect of the enzyme concentration in the glycerolysis reaction}

Enzymes require a minimum amount of water to maintain their structure and flexibility. Moreover, water content is necessary because these enzymes act at the oil-water interface. Since the raw material contained $1.1 \%$ of water (Table 2 ), which was considered sufficient for the reaction to run successfully based on the working specifications set for lipases (Table 1), further amounts of water were not added to the reaction mixtures.

In this experiment, an average performance of $58.6 \% \pm 0.6$ was found for all experimental conditions with enzyme concentrations ranging from 0.5 to $3.5 \%$, which suggested that the yield of the enzymatic glycerolysis did not seem to depend on the dose of the enzyme (Figure 2). Based on these results, in the following set of experiments the enzyme dose was kept between $0.5-1.0 \%$ so as to reduce the costs of industrial processing. The amount of water measured in the final products was $2.7 \% \pm 0.3$.

Even in the presence of small amounts of water in the glycerolysis reaction medium, unwanted hydrolysis reactions must be considered (Solaesa et al., 2016). Taking into account that enzymatic glycerolysis produces up to 3 equivalents of water (equations 4 to 7), working at low pressure would favor the formation of MAG, DAG and TAG as water would be removed from the reaction medium as vapor.

In good agreement with this, when the enzymatic glycerolysis reaction was carried out under vacuum (2-3 mbar, enzyme concentration between $0.5-1.0 \%$ (oil weight)), the efficiency of the reaction increased by up to $>90 \%$ (Table 3 ) showing the beneficial effect of vacuum in the glycerolysis reaction. As for the enzyme dosage, increasing from 0.5 to $1.0 \%$ improved the reaction yield a further 5\% (from 90.3 to $95.1 \%$ ) generating an oil with an acidity below $2.5 \%$. Humidity was determined in the final reaction product at less than $0.1 \%$.

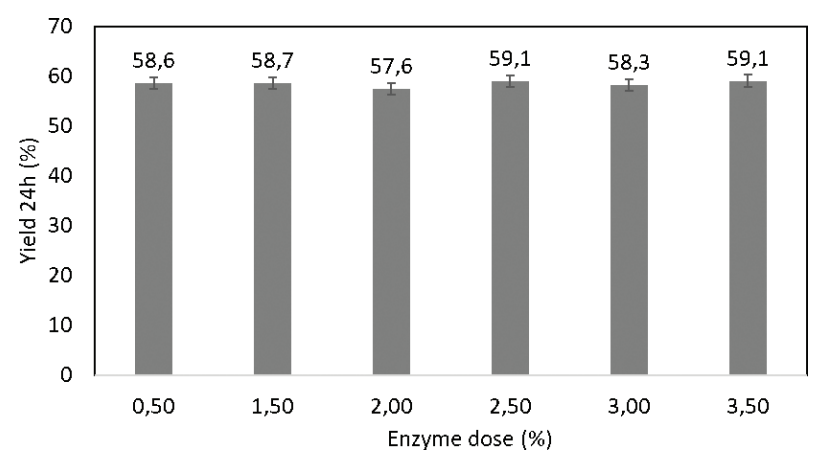

FIGURE 2. Effect of the enzyme dose in the yield of enzymatic glycerolysis reaction. Reaction condition: $65^{\circ} \mathrm{C}, 24 \mathrm{~h}, 800$ $\mathrm{rpm}, \mathrm{pH} 5.5$ and molar ratio glycerin/oil of $2: 1$. Each point represents the mean value of two replicates $+/-\mathrm{SD}$. 


\subsection{Effect of glycerol in enzymatic glycerolysis}

As can be observed in Figure 3, the yield of the enzymatic glycerolysis depended on the quantity of glycerol added, and ranged from 79 (using 16.7\% of glycerol) to $89 \%$ (using $45.9 \%$ of glycerol). In all conditions studied the acidity value was lower than $10 \%$.

When vacuum was applied (2-3 mbar), the reaction progressed favorably and acidity values below $7.0 \%$ were reached in all cases, while yields higher than $85 \%$ were obtained (Table 4). Humidity in the very final product was determined to be less than $0.1 \%$, reaching a similar acidity value (less than 7 ) in this group of experiments. As previously discussed in section 2.2, the MAG, DAG and TAG profiles were conditioned by the amount of glycerol used in the reaction medium (Table 4).

TABLE 3. Effect of using vaccum on acidity reduction in the enzymatic glycerolysis reaction with different enzyme doses. Reaction condition: $65^{\circ} \mathrm{C}, 24 \mathrm{~h}, 800 \mathrm{rpm}, \mathrm{pH} 5.5$ and molar ratio glycerin:oil 2:1. Each point represents the mean value of two replicates $+/-\mathrm{SD}$.

\begin{tabular}{lcc}
\hline Enzyme dose (\%) & Acidity $24 \mathbf{h}(\%)$ & Yield (\%) \\
\hline 0.5 & $4.5 \pm 0.1$ & $90.3 \pm 0.1$ \\
1.0 & $2.3 \pm 0.2$ & $95.1 \pm 0.4$ \\
\hline
\end{tabular}

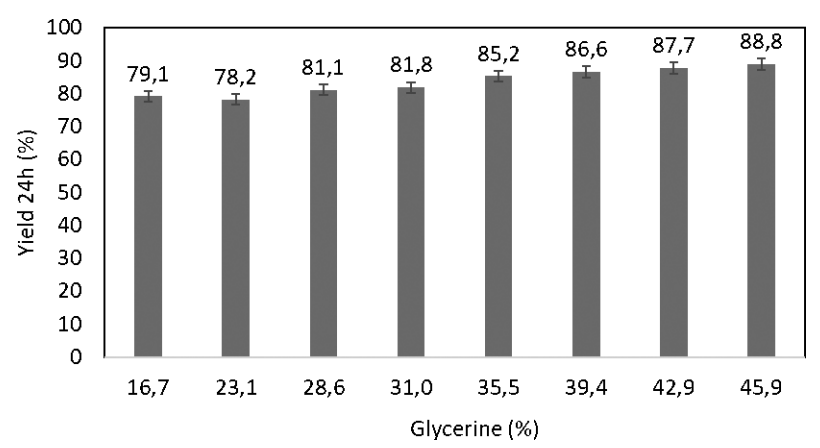

FIGURE 3. Effect of the glycerin concentration on the yield of the enzymatic glycerolysis reaction. Reaction condition: $65^{\circ} \mathrm{C}, 24 \mathrm{~h}$, $800 \mathrm{rpm}$, pH 5.5 and enzyme dose of Lipozyme CALB of 1\%. Each point represents the mean value of two replicates $+/-\mathrm{SD}$.
In the selected working conditions for this group of experiments glycerol was in stoichiometric defect with respect to FFA. Not surprisingly, in these working conditions MAG formation was favored, reaching the highest conversion at 9.2\% glycerol (molar ratio 0.6:1; glycerol:FFA). In this set of experiments (molar ratios glycerol:oil of $0.5: 1(7.0 \%), 0.6: 1(9.2 \%)$ y $0.75: 1(11.2 \%))$, TAG concentration was higher for lower concentrations of glycerol, which suggested that the content of MAG and DAG increased as TAG content decreased.

\subsection{Time period of the enzymatic glycerolysis reaction}

Samples were taken at 2, 4, 6 and $24 \mathrm{~h}$, following the procedure described by Choong (Choong et al., 2018). Time periods were studied for three different reactions: the first one with a molar ratio of oil:glycerol 1:2 (Figure 4A), the second with a molar ratio of oil:glycerol 1:1 (Figure 4B) and the last one using hydrolyzed cocoa olein as raw material (Figure 4C). The reaction conditions are described in detail in section 2.2. The composition of the hydrolyzed olein was $87.2 \%$ FFA, $0 \%$ MAG, 3.1\% DAG, 4.7\% TAG and $\mathrm{pH}$ 5.0. The enzymatic hydrolysis reaction had a yield of up to $80 \%$.

As previously stated, increasing the amount of glycerol in the reaction medium favored the formation of MAG and DAG (Table 5). When the raw material used for the enzymatic glycerolysis reaction was a material with high acidity and low TAG content (such as hydrolyzed cocoa olein) a final product with a high quantity of MAG and DAG $(77 \%)$ was obtained.

It is important to highlight that although the enzymatic glycerolysis reaction is usually a long process $(24 \mathrm{~h})$, when cocoa olein was used as raw material the reaction was completed in only 6-8 $\mathrm{h}$, regardless of the composition of the raw material (cocoa olein or hydrolyzed cocoa olein). This is noteworthy since previous studies on enzymatic glycerolysis reported longer reaction times $(20-72 \mathrm{~h})$ (Table 6).

TABLE 4. Effect of glycerin/oil molar ratio on product formation in the enzymatic glycerolysis reaction. Reaction condition: $65^{\circ} \mathrm{C}, 24 \mathrm{~h}, 800 \mathrm{rpm}, 2-3 \mathrm{mbar}, \mathrm{pH} 5.5$ and enzyme dose of $0.5 \%$. ${ }^{(1)} \mathrm{FFA}$ (free fatty acid); MAG (monoglycerides); DAG (diglycerides) and TAG (triglycerides). Each point represents the mean value of two replicates $+/-$ SD.

\begin{tabular}{|c|c|c|c|c|c|c|c|}
\hline Sample & $\begin{array}{c}\text { Glycerin } \\
(\%)\end{array}$ & $\begin{array}{c}\text { Water 24h } \\
(\%)\end{array}$ & $\begin{array}{c}\mathrm{FFA}^{(1)} \\
(\%)\end{array}$ & $\begin{array}{c}\mathrm{MAG}^{(1)} \\
(\%)\end{array}$ & $\begin{array}{c}\mathrm{DAG}^{(1)} \\
(\%)\end{array}$ & $\begin{array}{c}\text { TAG } \\
(\%)\end{array}$ & $\begin{array}{l}\text { Yield } \\
(\%)\end{array}$ \\
\hline Cocoa olein & 0.0 & $1.13 \pm 0.05$ & $46.3 \pm 2.3$ & $2.7 \pm 0.2$ & $7.7 \pm 0.4$ & $38.9 \pm 1.9$ & - \\
\hline \multirow[t]{3}{*}{ Final product } & 7.0 & $0.05 \pm 0.01$ & $7.0 \pm 0.4$ & $21.4 \pm 1.0$ & $34.1 \pm 1.7$ & $31.4 \pm 1.6$ & $84.9 \pm 0.9$ \\
\hline & 9.2 & $0.08 \pm 0.01$ & $4.7 \pm 0.3$ & $42.2 \pm 2.1$ & $21.5 \pm 1.1$ & $29.2 \pm 1.5$ & $89.8 \pm 0.1$ \\
\hline & 11.2 & $0.03 \pm 0.01$ & $2.1 \pm 0.1$ & $32.2 \pm 1.6$ & $34.1 \pm 1.7$ & $24.5 \pm 1.2$ & $95.6 \pm 0.1$ \\
\hline
\end{tabular}



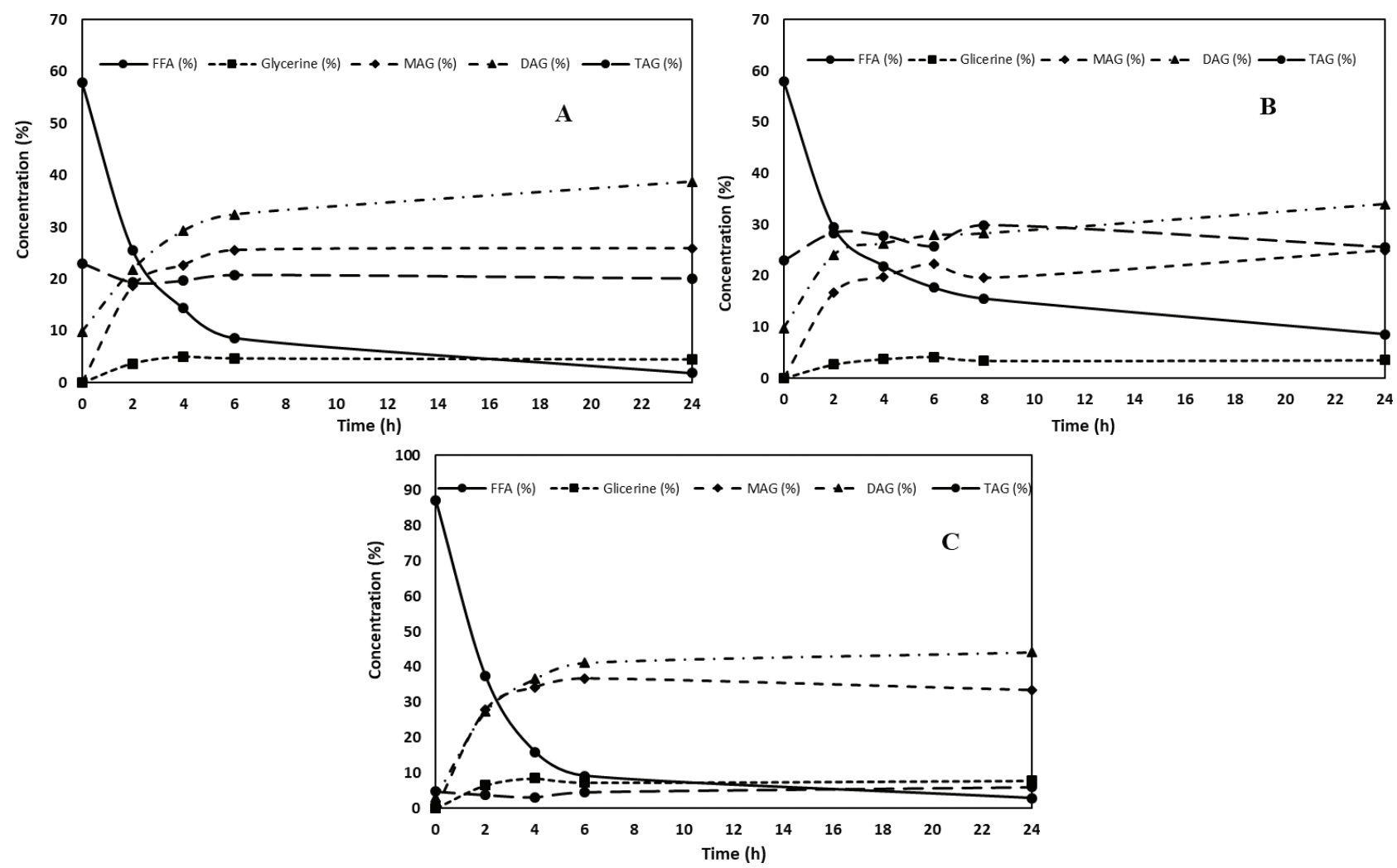

FIGURE 4. Time period of the enzymatic glycerolysis reaction. Reaction condition: $65^{\circ} \mathrm{C}, 24 \mathrm{~h}, 800 \mathrm{rpm}, \mathrm{pH} 5.5,2-3$ mbar, enzyme dose of Lipozyme CALB of 1\% and a molar ratio oil:glycerin of 1:2 (A); a molar ratio oil:glycerin of 1:1 (B) and a different raw material, the product from enzymatic hydrolysis of cocoa olein and a molar ratio oil:glycerin of 1:2 (C). FFA (free fatty acid); MAG (monoglycerides); DAG (diglycerides) and TAG (triglycerides). Each point represents the mean value of two replicates.

TABLE 5. Final product composition from the enzymatic glycerolysis reaction. Reaction condition: $65^{\circ} \mathrm{C}, 24 \mathrm{~h}, 800 \mathrm{rpm}$, 2-3 mbar, pH 5.5 and enzyme dose of $0.5 \% .{ }^{(1)} \mathrm{FFA}$ (free fatty acid); MAG (monoglycerides); DAG (diglycerides) and TAG (triglycerides). Each point represents the mean value of two replicates +/- SD.

\begin{tabular}{|c|c|c|c|c|c|c|}
\hline Raw material & Molar Ratio Oil:Glycerin & FFA $^{(1)}(\%)$ & Glycerin (\%) & $\operatorname{MAG}^{(1)}(\%)$ & $\operatorname{DAG}^{(1)}(\%)$ & TAG $^{(1)}(\%)$ \\
\hline Cocoa Olein & $1: 1$ & $8.6 \pm 0.4$ & $3.5 \pm 0.2$ & $24.9 \pm 1.2$ & $34.0 \pm 1.7$ & $25.6 \pm 1.0$ \\
\hline Cocoa Olein & $1: 2$ & $1.9 \pm 0.1$ & $4.4 \pm 0.3$ & $25.9 \pm 1.5$ & $38.8 \pm 1.5$ & $20.1 \pm 0.8$ \\
\hline Hydrolyzed Cocoa Olein & $1: 2$ & $2.9 \pm 0.2$ & $7.7 \pm 0.4$ & $33.4 \pm 2.0$ & $44.2 \pm 1.2$ & $5.9 \pm 0.4$ \\
\hline
\end{tabular}

\section{CONCLUSIONS}

The free lipase B of Candida antarctica was used in the glycerolysis of cocoa olein and produced an oil enriched in MAG and DAG in a solvent-free system. It was found that the maximum yield was reached when the reaction was carried out at low pressure (2-3 mbar) and at $65^{\circ} \mathrm{C}$, with an enzyme dose of $1 \%$ and a molar oil:glycerol ratio of $1: 2$. In addition, FFA enrichment of cocoa olein, used as raw material, yielded an improvement in the MAG/ DAG ratio which went from MAG/DAG $=26 / 39 \%$ to $\mathrm{MAG} / \mathrm{DAG}=33 / 44 \%$. Finally, we also observed a remarkable reduction in reaction time compared to the typical enzymatic processes described for this kind of reactions (Table 6).
The combination of shorter reaction times with decreasing prices of enzymes could pave the way for the scale up and industrialization of these processes for the valorization of by-products such as sunflower, soybean, olive, rapeseed and cocoa oleins from soapstocks.

\section{ACKNOWLEDGMENTS}

This work was performed within the framework of the project financially supported by the Gobierno de Navarra with action number 0011-1365-2017000040 with title "Industrial glycerolysis of oleaginous by-products catalyzed by enzymes to obtain monoglycerides (OLEOENZYGLY)", The authors wish to thank Novozymes for the enzymes used in this study. 


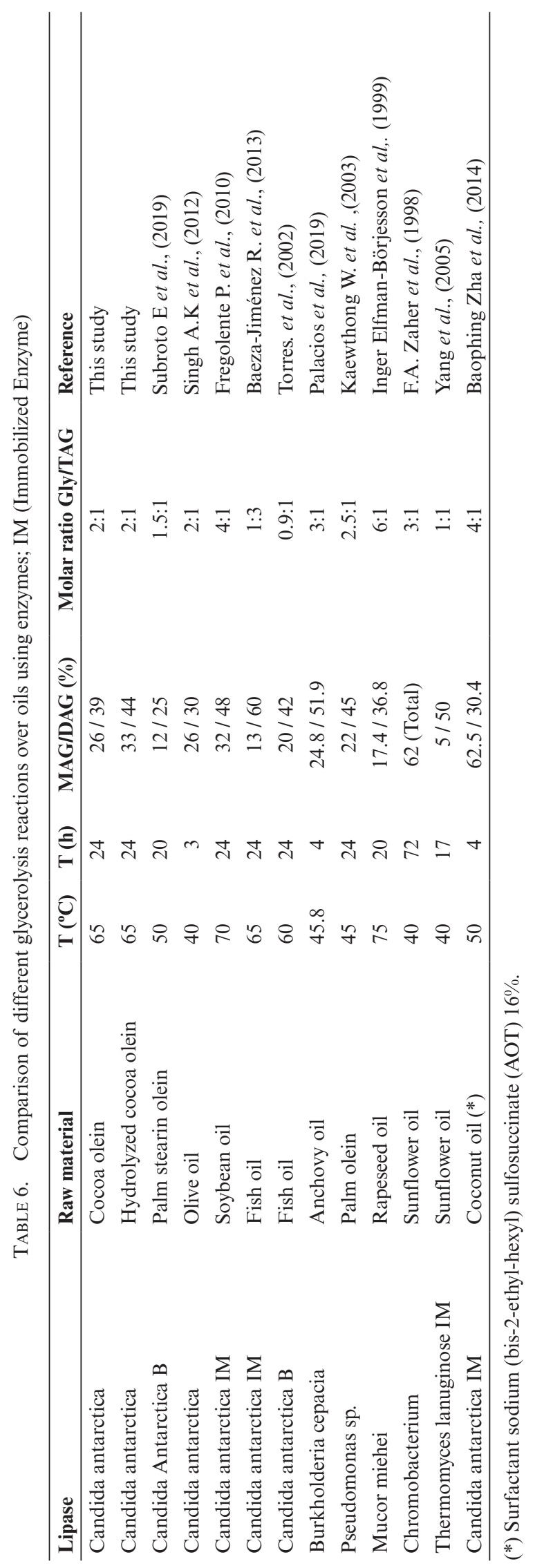

\section{REFERENCES}

Abdelmoez W, Mustafa A. 2014. Oleochemical industry future through biotechnology. J. Oleo Sci. 63 (6), 545-554. https:// doi.org/10.5650/jos.ess 14022

Baeza-Jiménez R, Miranda K, García HS, Otero C. 2013. Lipase-catalyzed glycerolysis of fish oil to obtain diacylglycerols. Grasas Aceites 64 (3), 237-242. https://doi. org/10.3989/gya.084412

Baoping Z, Zhongwei C, Li W, Ren W, Zhengxing C, Lianhe Z. 2014. Production of glycerol monolaurate- enriched monoacylglycerols by lipase-catalyzed glycerolysis from coconut oil. Eur. J. Lipid Sci. Technol. 116, 328-335. https://doi. org/10.1002/ejlt.201300243

Borrelli GM, Trono D. 2015. Recombinant Lipases and Phospholipases and Their Use as Biocatalysts for Industrial Applications. Int. J. Mol. Sci. 16, 20774-20840. https://doi. org/10.3390/ijms160920774

Camino Feltes MM, De Oliveira D, Mara Block J, Luiz Ninow J. 2013. The Production, Benefits, and Applications of Monoacylglycerols and Diacylglycerols of Nutritional Interest. Food Bioprocess Technol. 6, 17-35. https://doi. org/10.1007/s11947-012-0836-3

Camino Feltes MM, Villeneuve P, Baréa B, Barouh N, Vladimir de Oliveira J, De Oliveira D, Luiz Ninow J. 2012. Enzymatic Production of Monoacylglycerols (MAG) and Diacylglycerols (DAG) from Fish Oil in a Solvent-Free System. J. Am. Oil Chem. Soc. 89, 1057-1065. https://doi. org/10.1007/s11746-011-1998-2

Choong TSY, Yeoh CM, Phuah ET, Siew WL, Lee YY, Tang TK. 2018. Kinetic study of lipase-catalyzed glycerolysis of palm olein using Lipozyme TLIM in solvent-free system. PLoS One 13 (2), e0192375. https://doi.org/10.1371/journal.pone. 0192375

Csanádi Z, Bélafi-Bakó K, Gubicza L. 2009. Biocatalytic production of glycerol mono-stearate in non-conventional reaction media. New Biotechnology 25, Supplement Page S110. https://doi.org/10.1016/j.nbt.2009.06.388

Dias Ribeiro B, Machado de Castro A, Zarur Coelho MA, Guimaraes Freire DM. 2011. Production and Use of Lipases in Bioenergy: A Review from the Feedstocks to Biodiesel Production. Enzyme Res. 11, 1-16. https://doi. org/10.4061/2011/615803

Elfman-Börjesson I, Härröd M. 1999. Synthesis of Monoglycerides by Glycerolysis of Rapeseed Oil Using Immobilized Lipase. J. Am. Oil Chem. Soc. 76 (6), 701-707. https://doi.org/10.1007/s11746-999-0162-8

Fariha H, Aamer AS, Abdul H. 2006. Industrial applications of microbial lipases. Enzyme Microb. Technol. 39, 235-251. https://doi.org/10.1016/j.enzmictec.2005.10.016

Fregolente PBL, Vasconcelos Fregolente L, Maria Pinto G, César Batistella B, Wolf-Maciel MG, Maciel Filho R. 2008. Monoglycerides and Diglycerides Synthesis in a Solvent-Free System by Lipase-Catalyzed Glycerolysis. Appl. Biochem. Biotechnol. 146 (1-3), 165-172. https://doi. org/10.1007/s12010-008-8133-3

Fregolente PBL, Pinto GMF, Wolf-Maciel MR, Filho RM. 2010. Monoglyceride and diglyceride production through lipase-catalyzed glycerolysis and molecular distillation. Appl. Biochem. Biotechnol. 160 (7), 1879-1887. https://doi. org/10.1007/s12010-009-8822-6

Godfrey T. 1995. Lipases for industrial use. Lipid Technology.

Goswami D, De S, Basu JK. 2012. Effects of process variables and additives on mustard oil hydrolysis by porcine pancreas lipase. Braz. J. Chem. Eng. 29 (3), 449-460. https:// doi.org/10.1590/S0104-66322012000300002

Kaewthong W, Sirisansaneeyakul S, Prasertsan P, H-Kittikun A. 2005. Continuous production of monoacylglycerols by glycerolysis of palm olein by immobilized lipase. Process Biochem. 40, 218-222. https://doi.org/10.1016/j. procbio.2003.12.002

Kapoor M, Gupta MN. 2012. Obtaining monoglycerides by esterification of glycerol with palmitic acid using some high activity preparations of Candida antarctica lipase B. Process Biochem. 47, 503-508. https://doi.org/10.1016/j. procbio.2011.12.009 
Narvaez Rincón PC, Sánchez FJ, Alfonso Torres J, Ponce de León LF. 2004. Producción de ésteres metílicos de ácidos grasos: variables asociadas al proceso de transformación. Ing. Invest. 24 (002), 41-50. https://doi.org/10.15446/ing. investig

Noureddini H, Harmeier SE. 1998. Enzymatic glycerolysis of soybean oil. J. Am. Oil Chem. Soc. 75 (10), 1359-1365. https://doi.org/10.1007/s11746-998-0183-8

Otadi M, Shahraki A, Goharrokhi M, Bandarchian F. 2011. Reduction of free acids of waste oil by acid-catalyzed esterification. Procedia Eng. 18, 168-174. https://doi. org/10.1016/j.proeng.2011.11.027

Palacios D, Ortega N, Rubio-Rodríguez N, Busto MD. 2019. Lipase-catalyzed glycerolysis of anchovy oil in a solvent-free system: Simultaneous optimization of monoacylglycerol synthesis and end-product oxidative stability. Food Chem. 271, 372-379. https://doi.org/10.1016/j. foodchem.2018.07.184

Pereda Marín J, Barriga Mateos F, Álvarez-Mateos P. 2003. Use of residual soapstock from the refining of edible vegetable oils to make biodiesel. Grasas Aceites 54 (2), 130-137. https://doi.org/10.3989/gya.2003.v54.i2.255

Ramesh Rarokar N, Menghani S, Kerzare D, Bhujangrao Khedekar P. 2017. Progress in synthesis of monoglycerides for use in food and pharmaceuticals. J. Exp. Food Chem. 3 (3), 128-134. https://doi.org/10.4172/24720542.1000128

Rivera-Pérez C, García Carreño F. 2007. Enzimas lipolíticas y su aplicación en la industria del aceite. BioTecnología 11 (2), $37-45$

Satriana, Normalina A, Meldasari Lubis Y, Adisalamun, Supardan MD, Wan Aida WM. 2016. Diacylglycerolenriched oil production using chemical glycerolysis. Eur. J. Lipid Sci. Tech. 118 (12), 1880-1890. https://doi. org/10.1002/ejlt.201500489

Singh AK, Mukhopadhyay M. 2012. Olive oil glycerolysis with the immobilized lipase Candida antarctica in a solvent free system. Grasas Aceites 63 (2), 202-208. https://doi. org/10.3989/gya.094811

Solaesa ÁG, Sanz MT, Falkeborg M, Beltrán S, Guo Z. 2016. Production and concentration of monoacylglycerols rich in omega-3 polyunsaturated fatty acids by enzymatic glycerolysis and molecular distillation. Food Chem. 190, 960-967. https://doi.org/10.1016/j.foodchem.2015.06.061

Solaesa ÁG, Sanz MT, Beltrán S, Melgosa R. 2016. Kinetic study and kinetic parameters of lipase-catalyzed glycerolysis of sardine oil in a homogeneous medium. Chinese J. Catal. 37. 596-606. http://doi.org/10.1016/S1872-2067(15)61040-3

Subroto E, Supriyanto, Utami T, Hidayat C. 2019. Enzymatic glycerolysis-interesterification of palm stearin-olein blend for synthesis structured lipid containing high mono- and diacylglycerol. Food Sci. Biotechnol. 28 (2), 511-517. https://doi.org/10.1007/s10068-018-0462-6

Torres C, Lin B, Hill C.G. 2002. Lipase-catalyzed glycerolysis of an oil rich in eicosapentaenoic acid residues. Biotechnol. Lett. 24, 667-673. https://doi.org/10.1023/A:1015298728683

Valério A, Rovani S, Treichel H, De Oliveira, Oliveira JV. 2010. Optimization of mono and diacylglycerols production from enzymatic glycerolysis in solvent-free systems. Bioproc. Biosyst. Eng. 33, 805-812. https://doi.org/10.1007/ s00449-009-0402-1

Vázquez L, González N, Reglero G, Torres C. 2016. SolventFree Lipase-Catalyzed Synthesis of Diacylglycerols as Low-Calorie Food Ingredientes. Front. Bioeng. Biotechnol. 4 (6), 1-10. https://doi.org/10.3389/fbioe.2016.00006

Wiphum Kaewthonga, Sarote Sirisansaneeyakulb, Poonsuk Prasertsana, AranH-Kittikuna. 2005. Continuous production of monoacylglycerols by glycerolysis of palm olein with immobilized lipase. Process Biochem. 40 (5), 1525-1530. https://doi.org/10.1016/j.procbio.2003.12.002

Yang T, Rebsdorf M, Engelrud U,XuX.2005. Enzymatic Production of Monoacylglycerols Containing Polyunsaturated Fatty Acids through an Efficient Glycerolysis System. J. Agric. Food Chem. 53 (5), 1475-1481. https://doi.org/10.1021/jf048405g

Yang T, Rebsdorf M, Engelrud U, Xu X. 2005. Monoacylglycerol synthesis via enzymatic glycerolysis using a simple and efficient reaction system. J. Food Lipids. 12, 299-312. https:// doi.org/10.1111/j.1745-4522.2005.00025.x

Zaher FA, Saadia M, Aly OS, El-Kinawy 1998 Lipase Catalyzed glycerolysis of sunflower oil to produce partial glycerides. Grasas Aceites 49 (5-6), 411-414. https://doi. org/10.3989/gya.1998.v49.i5-6.750

Zhao X, Fan M, Zeng J, Du W, Liu C, Liu D. 2013. Kinetics of lipase recovery from the aqueous phase of biodiesel production by macroporous resin adsorption and reuse of the adsorbed lipase for biodiesel preparation. Enzyme Microb. Tech. 52, 226-233. https://doi.org/10.1016/j. enzmictec. 2013.02 .006

Ziobrowski Z, Kiss K, Krupiczka R, Rotkegel A, Gubicza L, Nemestothy N. 2009. Pervaporation aided enzymatic production of glycerol monostearate in organic solvents. Desalination. 241, 212-217. https://doi.org/10.1016/j.desal.2008.01.067 